\title{
Erratum to: Factors influencing the entrepreneurial engagement of opportunity and necessity entrepreneurs
}

\author{
Peter van der Zwan ${ }^{1} \cdot$ Roy Thurik $^{1,3}$ (D) \\ Ingrid Verheul $^{2} \cdot$ Jolanda Hessels ${ }^{1}$
}

\section{Erratum to: Eurasian Bus Rev \\ DOI 10.1007/s40821-016-0065-1}

Due to a technical mistake in Table 3 the asterisks were placed after the second value (standard errors) instead of after the first value (coefficient). In addition there should have been parentheses around the second values (standard errors) in lines. The publisher apologizes for this mistake. The original article was corrected.

The online version of the original article can be found under doi:10.1007/s40821-016-0065-1.

Peter van der Zwan

vanderzwan@ese.eur.nl

1 Erasmus School of Economics, Erasmus University Rotterdam, P.O. Box 1738, 3000 DR Rotterdam, The Netherlands

2 Rotterdam School of Management, Erasmus University Rotterdam, P.O. Box 1738, 3000 DR Rotterdam, The Netherlands

3 Montpellier Business School, 2300 Avenue des Moulins, 34185 Montpellier Cedex 4, France 